\title{
Possible control of Senna spectabilis (Caesalpiniaceae), an invasive tree in Mahale Mountains National Park, Tanzania
}

\author{
James V. Wakibara and Bakari J. Mnaya
}

\begin{abstract}
Senna spectabilis is a tree native to South and Central America. Thirty-five years ago it invaded the Mahale Mountains National Park in western Tanzania where it presently covers c. 225 ha. We quantified its occurrence relative to that of sympatric species of native trees, and compared girdling and felling as methods for its control in three 0.25 ha plots. Within invaded areas of forest this exotic species was both the most abundant and dominant of the 26 species of tree recorded. During 4 years of monitoring the experimental plots the abundance of $S$. spectabilis declined markedly in the plots where control methods were practised, but increased slightly in
\end{abstract}

the unmanipulated plot. In contrast, the abundance of native tree species increased markedly in the plots where S. spectabilis had been removed or killed, with higher densities in the girdled rather than the felled plot. S. spectabilis appears to suppress the recruitment of native trees in the Park, and its removal can encourage regeneration of the degraded forest without the need for artificial seeding.

Keywords Caesalpiniaceae, control, exotic species, invasive tree, Senna spectabilis, Tanzania.

\section{Introduction}

Invasive plants are undesirable, especially in nature reserves, because their disruptive effects on the biota of invaded habitats are hard to predict (Lodge, 1993). They may, for instance, reduce the diversity of native species or alter soil chemistry, sedimentation levels, hydrological processes, fire regimes and even animal food sources (Cronk \& Fuller, 1995; Callaway \& Aschehoug, 2000; Christian, 2001). The best way to avoid these problems is to prevent the introduction of invasive plants into non-native regions, but increasing global trade and human mobility has facilitated mixing of fauna and flora across biogeographical boundaries (Sykora, 1990). Where plant invasion succeeds, the cost of restoration can be high (David et al., 2001). Thus, exotic plants should always be viewed as potentially harmful, and be carefully monitored.

Senna spectabilis H.S. Irwin \& R.C. Barneby (Caesalpiniaceae) (syn. Cassia spectabilis DC) is a tree native to Central and South America (Irwin \& Barneby, 1982). In 1967 it was transferred from the village of Katumbi, western Tanzania, into what is now Mahale

James V. Wakibara ${ }^{1}$ (Corresponding author) and Bakari J. Mnaya, Tanzania National Parks, P.O. Box 3134, Arusha, Tanzania

${ }^{1}$ Present address: Department of Zoology, Kyoto University, Sakyo-ku, Kyoto 606-8502 Japan. E-mail: wakibara@jinrui.zool.kyoto-u.ac.jp

Received 18 October 2001. Revision requested 6 March 2002. Accepted 28 May 2002
Mountains National Park, located c. $17 \mathrm{~km}$ south of the village (Fig. 1). It was initially planted to create shade but later the farmers grew it as living fences to prevent crop damage by animals (M.K. Seif, pers. comm.). At the time, slash-and-burn cultivation was common at the site and probably prevented the spread of this fireintolerant exotic (S. Uehara, pers. comm.). In 1975 the inhabitants of Mahale were relocated following government plans to establish a National Park, following which S. spectabilis has flourished.

S. spectabilis grows extremely fast (Garrity \& Mercado, 1994) and flourishes on acidic and infertile soils (Maclean et al., 1992). It flowers and sets seed precociously, (Mbuya et al., 1994), and the seed remains viable for up to 3 years (Watkins, 1960). It resprouts quickly, profusely, and persistently when cut. Garrity \& Mercado (1994) were able to harvest a high biomass of cuttings in each of the four consecutive years that they pruned S. spectabilis. The species is non-nodulating, but accumulates nitrogen efficiently, at times even exhausting soil nitrogen reserves (Maclean et al., 1992; Hulugalle \& Ndi, 1993; Ladha et al., 1993).

S. spectabilis is not recorded in the Global Invasive Species Database (2002), even though it has also escaped from Trinidad and Tobago and invaded the northern parts of Orinoco in Venezuela (Irwin \& Barneby, 1982). It is a useful tree in Tanzania (Mbuya et al., 1994), but is also recognized as invasive in parts of both Tanzania and Uganda (Anon., 2000; C.A. Chapman, pers. comm.). At Mahale it is found in c. 225 ha of once native forest (Ruffo, 1995). Such coverage may seem relatively minor, 


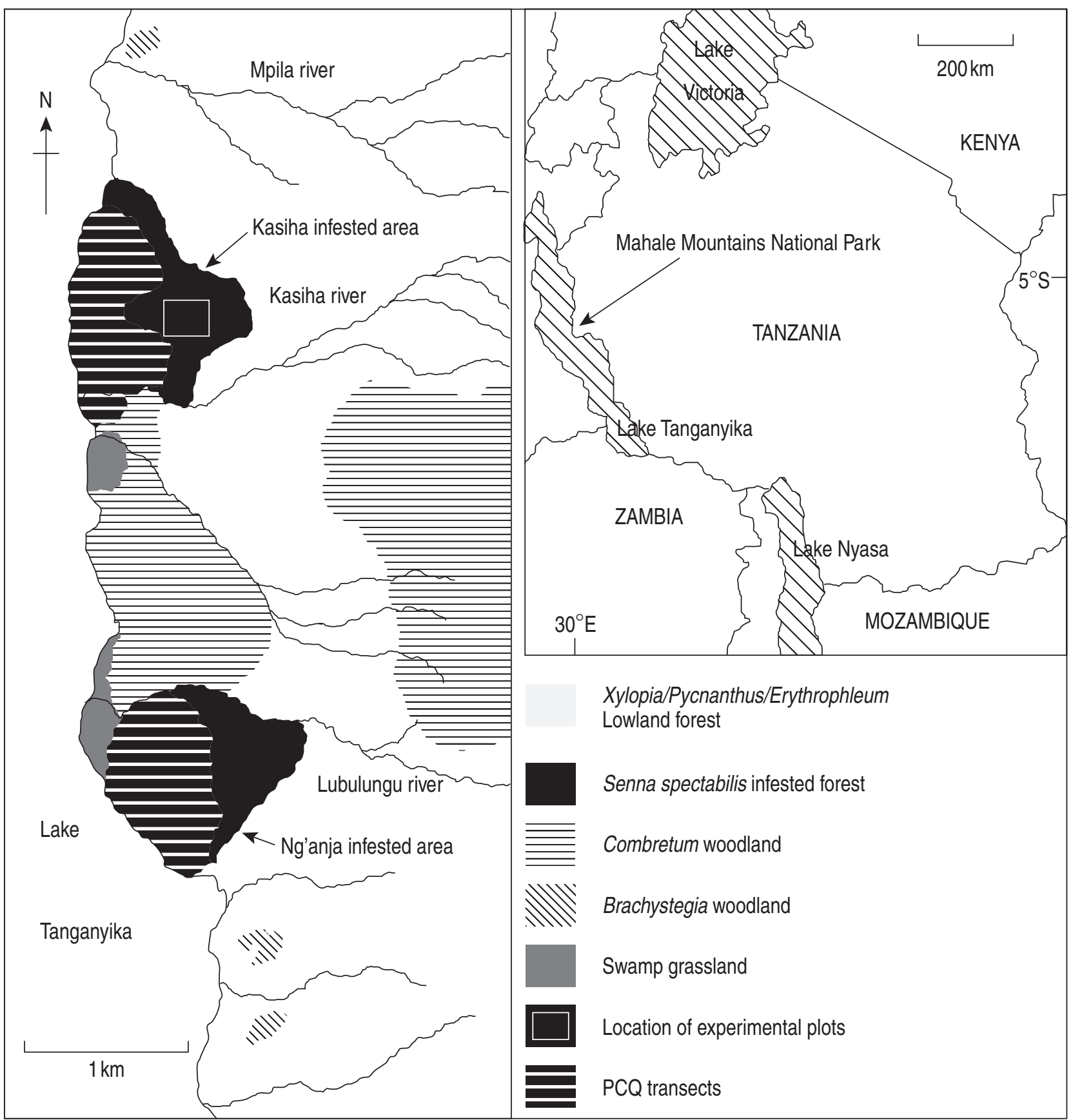

Fig. 1 Map of the study site showing the location of the three experimental plots, the survey transects, major vegetation types (after Turner, 2000), and the areas heavily infested with Senna spectabilis. The location of Mahale Mountains National Park is indicated on the inset.

given the Park's total area of c. 161,300 ha, but it amounts to $10 \%$ of the core feeding range of one group of chimpanzees Pan troglodytes schweinfurthii, the species that the park was primarily established to conserve (Fig. 1). Garrity \& Mercado (1994) noted that S. spectabilis is unpalatable to ruminants, and of the 13 forest mammals at Mahale only two have been confirmed to consume parts of this exotic (Ihobe, unpub. data).
Mahale Mountains National Park $\left(1,613 \mathrm{~km}^{2}\right)$ is located in western Tanzania (Fig. 1). The park's name describes its massif of several mountains, the highest of which is Nkungwe at 2,460 m. Annual rainfall averages 1,500-2,300 mm, and falls mainly during NovemberMay. June to October is usually dry (Takasaki et al., 1990). The vegetation of the area is a mosaic of forests, woodlands and swamp grassland (Fig. 1) (Turner, 2000). 
Ruffo (1995) quantified S. spectabilis invasion at Mahale, and Wakibara (1998) initiated experiments for its control. However, both of these studies were preliminary. Here, we further quantify its occurrence relative to that of native tree species in the section of forest that has been invaded, and quantify recruitment of the native tree species in experimental plots four years after girdling or felling of S. spectabilis.

\section{Methods}

From 27 December 1999 to 5 January 2000 we used the Point-Centred Quarter technique (Cottam \& Curtis, 1956) to assess the intensity of $S$. spectabilis invasion. A survey baseline was set approximately parallel to the shore of Lake Tanganyika, and 11 transects of 500-700 m length (a total length of $5.9 \mathrm{~km}$ ), separated by $100 \mathrm{~m}$ or more, were run eastwards, perpendicular to the baseline; the length of individual transects depended on the nature of the terrain (Fig. 1). We chose at random 82 sampling points, at least $50 \mathrm{~m}$ apart along the transects. There were 3-10 sampling points per transect depending on its length. At each sampling point we identified the nearest tree in each quadrant of the compass with a diameter at breast height (DBH, $1.3 \mathrm{~m}$ above the ground) $\geqslant 10 \mathrm{~cm}$ and recorded its DBH and its distance from the sampling point. We used the average distance from the sampling points to the trees to calculate the number of trees per ha (Cottam \& Curtis, 1956). We also determined the relative dominance of each tree species recorded.

In March 1996 we demarcated three 0.25 ha plots in an area of forest severely infested with $S$. spectabilis (Fig. 1). Delimiting growth stages as trees (DBH $>10 \mathrm{~cm})$, poles $(\mathrm{DBH} 2-10 \mathrm{~cm})$, saplings $(\mathrm{DBH}<2 \mathrm{~cm}$, height $>1.5 \mathrm{~m}$ ) and seedlings (height $<1.5 \mathrm{~m}$ ) (Okimori \& Matius, 2000), we counted all individuals in the three plots. In the first plot we girdled all S. spectabilis trees c. $60 \mathrm{~cm}$ above ground level, in the second we felled all $S$. spectabilis trees, and we left the third untouched as a control. In the two experimental plots we cut all S. spectabilis poles and saplings and uprooted germinating seedlings 2-3 times per week. It took 14 days for a team of 10 to fell and girdle the two plots. Intervention was terminated after 90 days, following which relatively few new $S$. spectabilis seedlings germinated. We neither treated the plots with herbicides nor artificially enriched them with native tree propagules.

\section{Results}

We sampled a total of 328 'closest individual' trees of 26 species in 15 plant families along the 11 transects.
The density of $S$. spectabilis was 586 trees $\mathrm{ha}^{-1}$, whereas that of the native species was 1-43 trees ha ${ }^{-1}$ (Table 1). S. spectabilis was both the most abundant and most dominant tree species (Table 1).

Before intervention there were no significant differences between the three plots in the combined number of seedlings and saplings, or poles and trees, for either S. spectabilis or native species (Table 2). Four years after intervention the numbers of $S$. spectabilis were significantly lower in the felled and girdled plots compared to the control plot, whereas in the latter the number of S. spectabilis had increased slightly (Table 2). Intervention enhanced the regeneration of native tree species, with significant increases compared to the control, and with the greatest increases in the girdled plot (Table 2).

Twenty-seven native tree species were recorded in the experimental plots after 4 years (Table 3 ). Nineteen $(70 \%)$ of these were also recorded in the transect survey of the infested forest (Table 1). After 4 years, 11, 6 and 3 tree species, respectively, were recorded in the girdled, felled and control plots that had not been present at the time of the initial survey.

\section{Discussion}

Our results indicate that $S$. spectabilis suppresses the growth of native tree species at Mahale, and that its removal allows their natural regeneration. Similarly Turner (2000) recently found that tree diversity at Mahale was lower in S. spectabilis dominated areas than in intact forests. A caveat to our results is that we only monitored the plots for 4 years, and used only three plots, in an area where $S$. spectabilis invasion was most severe. In areas where $S$. spectabilis is less dense its response to intervention could differ, and therefore caution is necessary in extrapolating our findings to all of the invaded area.

How this exotic tree suppresses the growth of native trees at Mahale is unknown. Hulugalle \& Ndi (1993) suggested that $S$. spectabilis is allelopathic, but it is the legume of choice in hedge cropping systems (Mathews et al., 1992a, b), and Maclean et al. (1992) showed that it is not allelopathic to maize or rice.

A previous attempt to control S. spectabilis at Mahale by felling alone was frustrated by profuse sprouting of the stumps (Turner, 1996; A.H. Seki, pers. comm.). Successful control appears to require either girdling or felling, in combination with removal of seedlings and sprouts. In particular, we found that the removal of S. spectabilis seedlings from the cleared plots is crucial for the regeneration of native tree seedlings, but it takes more time than tree felling or girdling alone. The girdled plot recruited both the highest number of species and 
Table 1 Density and dominance of Senna spectabilis relative to sympatric tree species in the infested forest.

\begin{tabular}{|c|c|c|c|c|}
\hline Species & Family & Number of trees ha ${ }^{-1}$ & Relative density ${ }^{\mathrm{a}}(\%)$ & Relative dominance $(\%)$ \\
\hline Senna spectabilis & Caesalpiniaceae & 586.10 & 72.87 & 47.76 \\
\hline Trema orientalis & Ulmaceae & 42.62 & 3.66 & 2.94 \\
\hline Annona senegalensis & Annonaceae & 34.34 & 3.05 & 2.63 \\
\hline Harungana madagascariensis & Guttiferae & 27.90 & 2.74 & 0.24 \\
\hline Sterculia tragacantha & Sterculiaceae & 20.70 & 3.05 & 6.76 \\
\hline Bridelia micrantha & Euphorbiaceae & 12.72 & 1.22 & 2.13 \\
\hline Antidesma membranaceum & Euphorbiaceae & 12.57 & 1.83 & 0.68 \\
\hline Unidentified 1 & & 12.49 & 0.61 & 0.73 \\
\hline Erythrina abyssinica & Papilionaceae & 11.50 & 0.61 & 5.36 \\
\hline Acacia sieberiana & Mimosaceae & 11.27 & 0.91 & 9.03 \\
\hline Dracaena reflexa & Agavaceae & 9.97 & 0.91 & 0.38 \\
\hline Azanza garckeana & Malvaceae & 9.58 & 0.91 & 0.09 \\
\hline Brideria atroviridis & Euphorbiaceae & 9.43 & 0.61 & 0.38 \\
\hline Xylopia parviflora & Annonaceae & 8.51 & 0.61 & 0.62 \\
\hline Tabernaemontana holstii & Apocynaceae & 7.27 & 1.22 & 0.49 \\
\hline Ficus exasperata & Moraceae & 6.82 & 0.91 & 0.49 \\
\hline Ziziphys mucronata & Rhamnaceae & 6.29 & 0.61 & 0.43 \\
\hline Stereospermum kunthianum & Bignoniaceae & 5.52 & 0.61 & 0.14 \\
\hline Unidentified 2 & & 5.21 & 0.61 & 0.08 \\
\hline Spathoidea nilotica & Bignoniaceae & 3.90 & 0.61 & 2.75 \\
\hline Ficus vallis-choudae & Moraceae & 3.83 & 0.34 & 3.83 \\
\hline Albizia gummifera & Mimosaceae & 2.75 & 0.30 & 0.72 \\
\hline Albizia glaberrima & Mimosaceae & 2.29 & 0.30 & 8.52 \\
\hline Celtis africana & Mimosaceae & 2.06 & 0.30 & 2.67 \\
\hline Erythrophleum suaveolens & Caesalpinaceae & 1.76 & 0.30 & 0.12 \\
\hline Pseudopondias microcarpa & Anacardiaceae & 0.92 & 0.30 & 0.03 \\
\hline TOTAL & & 858.32 & 100 & 100 \\
\hline
\end{tabular}

(a) Number of stems of a given species/number of stems of all tree species $\times 100$.

(b) Total basal area of a given species/total basal area of all species $\times 100$.

Table 2 Density (stems ha ${ }^{-1}$ ) of seedlings and saplings combined, and poles and trees combined (see text for details) of Senna spectabilis and native tree species in two 0.25 ha experimental plots and a control plot at Mahale National Park before (March 1996) and after (Feb. 2001) S. spectabilis trees were felled or girdled. Figures in parentheses are the percentage change in numbers following intervention.

\begin{tabular}{|c|c|c|c|c|c|}
\hline & \multicolumn{3}{|l|}{ Plot type } & \multirow[b]{2}{*}{$\chi^{2}$} & \multirow[b]{2}{*}{$\mathrm{P}$} \\
\hline & Felled & Girdled & Control & & \\
\hline \multicolumn{6}{|c|}{ S. spectabilis (seedlings \& saplings) } \\
\hline Before & 11,592 & 11,004 & 11,120 & 2.8 & 0.3020 \\
\hline After & $496(-95.7)$ & $1,368(-87.6)$ & $11,620(+4.3)$ & 2005.7 & $<0.0001$ \\
\hline \multicolumn{6}{|c|}{ S. spectabilis (poles \& trees) } \\
\hline Before & 5,684 & 4,800 & 5,248 & 9.3 & 0.0094 \\
\hline After & $144(-97.5)$ & $792(-83.5)$ & $7,132(+35.9)$ & 1311.4 & $<0.0001$ \\
\hline \multicolumn{6}{|c|}{ Native species (seedlings \& saplings) } \\
\hline Before & 312 & 364 & 404 & 1.5 & 0.4792 \\
\hline After & $600(+92.3)$ & $2,812(+672.5)$ & $496(+22.8)$ & 293.9 & $<0.0001$ \\
\hline \multicolumn{6}{|c|}{ Native species (poles \& trees) } \\
\hline Before & 448 & 348 & 288 & 4.5 & 0.1070 \\
\hline After & $1,592(+255.4)$ & $3,992(+1047.1)$ & $388(+34.7)$ & 448.5 & $<0.0001$ \\
\hline
\end{tabular}

individuals of native trees, perhaps because the retention of some forest structure is favourable for recolonization by native species. As girdling is also less time-consuming than felling, it is probably a better method for the control of S. spectabilis. In the experimental plots Harungana madagascariensis and Trema orientalis are the two pioneer native tree species most likely to regenerate in areas cleared of S. spectabilis. 
Table 3 Number of trees per ha in the experimental plots before and after girdling or felling of Senna spectabilis. Numbers in parentheses are those before intervention.

\begin{tabular}{|c|c|c|c|c|}
\hline \multirow[b]{2}{*}{ Species } & \multirow[b]{2}{*}{ Family } & \multicolumn{3}{|l|}{ Plot type } \\
\hline & & Felled & Girdled & Control \\
\hline Senna spectabilis & Caesalpinaceae & $0(640)$ & $31(604)$ & $856(528)$ \\
\hline Trema orientalis & Ulmaceae & $600(32)$ & $564(28)$ & $20(16)$ \\
\hline Harungana madagascariensis & Guttiferae & $44(8)$ & $276(28)$ & $20(12)$ \\
\hline Ficus exasperata & Moraceae & $80(8)$ & $44(4)$ & $32(4)$ \\
\hline Grewia platyclada & Tiliaceae & $0(0)$ & $92(0)$ & $0(0)$ \\
\hline Cordia millenii & Boraginaceae & $32(0)$ & $56(0)$ & $0(0)$ \\
\hline Ficus vallis-choudae & Moraceae & $32(12)$ & $48(4)$ & $4(4)$ \\
\hline Antidesma membranaceum & Euphorbiaceae & $0(0)$ & $48(4)$ & $32(8)$ \\
\hline Canthium venosum & Rubiaceae & $0(0)$ & $40(8)$ & $4(4)$ \\
\hline Pseudopondias microcarpa & Anacardiaceae & $4(0)$ & $36(4)$ & $4(0)$ \\
\hline Xylopia parviflora & Annonaceae & $0(0)$ & $16(0)$ & $4(4)$ \\
\hline Tabernaemontana holstii & Apocynaceae & $12(4)$ & $8(8)$ & $0(0)$ \\
\hline Stereospermum kunthianum & Bignoniaceae & $4(4)$ & $4(4)$ & $12(0)$ \\
\hline Sterculia tragacantha & Sterculiaceae & $0(0)$ & $16(16)$ & $0(0)$ \\
\hline Erythrophleum suaveolens & Caesalpinaceae & $0(0)$ & $12(4)$ & $4(0)$ \\
\hline Dracaena reflexa & Agavaceae & $4(4)$ & $12(4)$ & $0(0)$ \\
\hline Cordia africana & Boraginaceae & $4(0)$ & $12(4)$ & $0(0)$ \\
\hline Brideria atroviridis & Euphorbiaceae & $4(4)$ & $0(0)$ & $18(16)$ \\
\hline Annona senegalensis & Annonaceae & $4(0)$ & $0(0)$ & $12(12)$ \\
\hline Azanza garckeana & Malvaceae & $0(0)$ & $8(0)$ & $0(0)$ \\
\hline Albizia glaberrima & Mimosaceae & $4(4)$ & $8(0)$ & $8(8)$ \\
\hline Ziziphys mucronata & Rhamnaceae & $0(0)$ & $4(0)$ & $0(0)$ \\
\hline Margaritaria discoidea & Euphorbiaceae & $4(0)$ & $4(0)$ & $0(0)$ \\
\hline Blighia unijugata & Sapindaceae & $0(0)$ & $4(0)$ & $4(4)$ \\
\hline Grewia mollis & Tiliaceae & $4(0)$ & $0(0)$ & $0(0)$ \\
\hline Croton sylvaticus & Euphorbiaceae & $0(0)$ & $4(0)$ & $0(0)$ \\
\hline Celtis africana & Ulmaceae & $0(0)$ & $4(0)$ & $0(0)$ \\
\hline Acacia sieberiana & Mimosaceae & $0(0)$ & $4(0)$ & $0(0)$ \\
\hline TOTAL & & $836(720)$ & 1355 (724) & $1034(620)$ \\
\hline
\end{tabular}

Seedling enrichment, as suggested by Ruffo (1995), was not necessary. In a separate trial (unpub. data) we found that native seedlings transplanted into a patch cleared of $S$. spectabilis were soon uprooted by forest mammals. The seeds of the native tree species that germinated in the experimental plots could have been part of the soil seed-bank and/or deposited by frugivores. Fruit-eating animals, mostly primates, frequently traversed the experimental plots. In the forest of Kibale National Park, Uganda, Chapman \& Chapman (1996) observed that chimpanzee dung contained viable seeds which assisted in the regeneration of forest patches degraded by logging.

Although S. spectabilis was introduced into Mahale 35 years ago, it has spread slowly and currently infests only c. 225 ha of the c. 3,000 ha of forest immediately vulnerable to its invasion frontier. S. spectabilis competes aggressively in disturbed forests and forest gaps but not in closed canopies (Irwin \& Barneby, 1982), which is typical of most invasive plant species (Kornas, 1990; Duggin \& Gentle, 1998). Duggin \& Gentle (1998) considered an intact canopy to be the most effective barrier against invasion of forest by Lantana camara in Australia. Similarly, Mugasha et al. (2000) concluded that the spread of Maesopsis eminii on Tanzania's East Usambara Mountains declined following reduced forest disturbance by humans. The restricted distribution and slow rate of spread of $S$. spectabilis at Mahale offers an opportunity for its containment and possible control. It would probably be best to destroy the outlying pockets of invasion before tackling the main infestation (Moody \& Richard, 1988).

In conclusion, Senna spectabilis appears to suppress the regeneration and growth of native tree species at Mahale Mountains National Park, and we have shown that there are potential options for its control. The Tanzania National Parks authority forbids the introduction of exotic species into the parks and supports 
initiatives for their removal. Following on from our experimental results, Tanzania National Parks is presently soliciting funds for a control programme for this damaging exotic tree species.

\section{Acknowledgements}

We thank Tanzania National Parks, ANICA Inc., Japan, and Prof. T. Nishida of Kyoto University, Japan, for providing financial support, Martin Kupper for valuable professional advice, 10 field assistants who worked tirelessly in the field, and three anonymous reviewers who offered useful comments.

\section{References}

Anon. (2000) Preliminary survey of invasive species in Eastern Africa. In Proceedings of a Workshop on Invasive Species in Eastern Africa (eds E.E. Lyons \& S.E. Miller), p. 69. ICIPE Science Press, Nairobi, Kenya.

Callaway, R.M. \& Aschehoug, E.T. (2000) Invasive plants versus their new and old neighbors: A mechanism for exotic invasion. Science, 290, 521-523.

Chapman, C.A. \& Chapman, L.J. (1996) Exotic tree plantations and the regeneration of natural forests in Kibale National Park, Uganda. Biological Conservation, 76, 253-257.

Christian, C.E. (2001) Consequences of biological invasions reveal the importance of mutualism for plant communities. Nature, 413, 635-639.

Cottam, G. \& Curtis, J.T. (1956) The use of distance measures in phytosociological sampling. Ecology, 37, 451-460.

Cronk, Q.C.B. \& Fuller, J.L. (1995) Plant Invaders: The threat to natural ecosystems. In People and Plants Conservation Manual (ed. M. Walters), pp. 1-59. Chapman \& Hall, London, UK.

David, P., McNair, S., Janecka, J., Wightman, J., Simmonds, C.O., Connell, E., Wong, L., Russel, J., Zern, J., Aquino, T. \& Tsomondo, T. (2001) Economic and environmental threats of alien plant, animal and microbial invasions. Agriculture, Ecosystems \& Environment, 84, 1-20.

Duggin, J.A. \& Gentle, C.B. (1998) Experimental evidence on the importance of disturbance intensity for invasion of Lantana camara L. in dry rainforest - open forest ecotones in north-eastern NSW, Australia. Forest Ecology E Management, 109, 279-292

Garrity, D.P. \& Mercado A.R. (1994) Nitrogen fixation capacity in the component species contour hedge grows. How important? Agroforestry Systems, 22, 207-220.

Global Invasive Species Database (2002) Online at http:/ /www.issg.org, accessed 4 April 2002

Hulugalle, N.R. \& Ndi, J.N. (1993) Effects of no-tillage and alley cropping on soil properties and crop yields in Typic Kandiuludult of Southern Cameroon. Agroforestry Systems, 22, 207-220.
Irwin, H.S. \& Barneby, R.C. (1982) The American Cassiinae: A synoptical revision of Leguminoeae tribe Cassiinae in the New World. Memoirs of The New York Botanical Garden, 35, 455-918.

Kornas, J. (1990) Plant invasions in Central Europe: Historical and ecological aspects. In Biological Invasions in Europe and the Mediterranean Basin (eds F. di Castri, A.J. Hansen \& M. Debussche), pp. 19-36. Kluwer Academic Publishers, Dordrecht, Netherlands.

Ladha, J.K., Peoples, D.P., Garrity, D.P., Capuno, V.T. \& Dart, P.J. (1993) Estimating di-nitrogen fixation of hedgerow vegetation using the nitrogen-15 natural abundance method. Soil Science Society of America Journal, 57, 732-737.

Lodge, D.M. (1993) Biological Invasions: Lessons for ecology. Trends in Ecology \& Evolution, 8, 133-137.

Maclean, R.H., Litsinger, J.A., Moody, K. \& Watson, A.K. (1992) The impact of alley cropping Gliricidia sepium and Cassia spectabilis on upland rice and maize production. Agroforestry Systems, 20, 213-228.

Mathews, R.B., Holden, S.T., Volk, J. \& Lungu, S. (1992a) The potential of alley cropping in improvement of cultivation systems in the high rainfall areas of Zambia: I. Chitemene and Fundikila. Agroforestry Systems, 17, 219-240.

Mathews, R.B., Lungu, S., Volk, J., Holden, S.T. \& Solberg, K (1992b) The potential of alley cropping in improvement of cultivation systems in high rainfall areas of Zambia: II. Maize production. Agroforestry Systems, 17, 241-261.

Mbuya, L.P., Msanga, H.P., Rufo, C.K., Birnie, A. \& Tengnas, B. (1994) Useful Trees and Shrubs for Tanzania. Identification, Propagation and Management of Agricultural and Pastoral Communities. Regional Soil Conservation Unit, Swedish International Development Authority, Nairobi, Kenya.

Moody, M.E. \& Richard, N.M. (1988) Controlling the spread of plant invasions: The importance of nascent foci. Journal of Applied Ecology, 25, 1009-1021.

Mugasha, A.G., Mgangamundo, M.A. \& Zahabu, E. (2000) Is Maesopsis eminii a problem in East Usambara forests? In Proceedings of a Workshop on Invasive Species in Eastern Africa, (eds E.E. Lyons \& S.E. Miller), pp. 59-64. ICIPE Science Press, Nairobi.

Okimori, Y. \& Matius, P. (2000) Tropical secondary forest and its succession following traditional slash-and-burn agriculture in Mencimai, East Kalimantan. In Rainforest Ecosystems of East Kalimantan. Ecological Series no. 140 (eds E. Guhardja, M. Fatawi, M. Sutsina, T. Mori \& S. Ohta), pp. 185-197. Springer-Verlag, Tokyo, Japan.

Ruffo, C.K. (1995) A Report on the Identification and Invasion of Senna Spectabilis in Mahale Mountains National Park, Tanzania. Unpublished report, Tanzania National Parks, Tanzania.

Sykora, K.V. (1990) History of the impact of man on the distribution of plant species. In Biological Invasions in Europe and the Mediterranean Basin (eds F. di Castri, A.J. Hansen \& M. Debussche), pp. 37-50. Kluwer Academic Publishers, Dordretch, Netherlands

Takasaki, H., Nishida, T., Uehara, S., Norikoshi, K., Kawanaka, K., Hiraiwa-Hasegawa, M., Hayaki, T., Masui, K. \& Huffman, M. (1990) Summary of meteorological data at Mahale research camps, 1973-1988. In The Chimpanzees of 
the Mahale Mountains, Sexual Life History Strategies

(ed. T. Nishida), pp. 285-300. University of Tokyo Press, Tokyo, Japan.

Turner, L.A. (1996) A Preliminary Assessment of Senna spectabilis, an Invasive Tree in Secondary Vegetation at Mahale Mountains National Park, Tanzania. Unpublished report.

Turner, L.A. (2000) Chimpanzee ranging and vegetation at Kasoje in Mahale Mountains National Park, Tanzania. PhD thesis, Kyoto University, Kyoto, Japan.

Wakibara, J.V. (1998) Observations on the pilot control of Senna spectabilis, an invasive exotic tree in the Mahale Mountains National Park, Western Tanzania. Pan Africa News, 5, 4-6.

Watkins, G. (1960) Trees and Shrubs for Planting in Tanganyika. Government Printers, Dar es Salaam, Tanzania.

\section{Biographical sketches}

James Wakibara has been a wildlife ecologist with Tanzania National Parks since 1995. He is currently pursuing a $\mathrm{PhD}$ at Kyoto University, Japan, focusing on dispersal of seeds by chimpanzees at Mahale. His major interest is in primateplant interactions.

Bakari J. Mnaya graduated in Wildlife Ecology \& Management at the University of Dar es Salaam, Tanzania. He has worked with Tanzania National Parks as an Ecologist since 1998 and carries out field research on biodiversity and conservation of forest ecosystems. 